\title{
KOMODITI GAMBIR SEBAGAI TANAMAN SELA DI ANTARA KARET UNTUK PENINGKATAN PENDAPATAN PETANI KARET (STUDI KASUS : DESA TOMAN, SUMATERA SELATAN)
} \author{
South Sumatra) \\ Iman Satra Nugraha, Aprizal Alamsyah dan Sahuri \\ Balai Penelitian Sembawa \\ Jalan Raya Palembang-Pangkalan Balai Km. 29 \\ Kotak Pos 1127 Palembang 30001, Sumatera Selatan \\ Email : iman_satra@yahoo.com
}

Gambir Commodities as Rubber Intercrops to Increase Farmer Income (Case Study of Toman District,

Diterima 22 November 2018 / Direvisi 6 Desember 2018/ Disetujui 20 Desember 2018

\begin{abstract}
Abstrak
Gambir (Uncaria gambir Roxb) adalah salah satu komoditas yang memiliki nilai ekonomis tinggi. Komoditas ini dapat dimanfaatkan untuk meningkatkan pendapatan petani karet melalui sistem usahatani terpadu yaitu sebagai tanaman sela karet. Tujuan tersebut sangat membantu karena saat ini harga karet masih rendah dan dapat meningkatkan produktivitas secara keseluruhan. Di Sumatera Selatan gambir hanya dapat menghasilkan getah yang tinggi di desa Toman karena spesifik lokasi sehingga petani di desa Toman melakukan integrasi gambir dengan karet untuk meningkatkan pendapatan. Berdasarkan pengamatan di lapangan, pendapatan yang diterima dari usahatani gambir lebih besar 11 $\%$ dibandingkan pendapatan dari karet. Pendapatan gambir sebesar Rp 2.792.944,- per ha per bulan sedangkan pendapatan usahatani karet sebesar Rp 2.507.500,- per ha per bulan. Rendahnya pendapatan dari karet disebabkan oleh harga karet yang belum stabil ditingkat dunia sehingga berdampak kepada harga ditingkat petani. Oleh karena itu, upaya untuk menjaga pendapatan petani diperlukan tanaman sela gambir dengan modifikasi jarak tanam karet melalui sistem jarak ganda untuk memperpanjang tanaman sela gambir.
\end{abstract}

Kata kunci : tanaman sela, gambir, karet, pendapatan

\begin{abstract}
Gambier is one a commodity that has high economic value. These conditions it can be used to increase the income of rubber farmers through an integrated farming system, gambier as intercrop to rubber crop. The is commodity was benifical since very helpful because at the end of this year rubber prices were still unstable. Therefore, it is necessary to integrate rubber plants with gambier. In for the South Sumatra region, gambier can only grow and produce sap in Toman Village. The farmers residents of Toman Village have integrated gambier with rubber to increase the in income. Based on field observations, the income received from gambir farming is $11 \%$ greater than rubber income. Gambier's revenue is $R p 2,792,944$ per ha per month while rubber farming income is $R p$ 2,507,500 per ha per month. The low rubber income is caused by the instable price of rubber that has not been stable at the world level so that it has an impact on the prices at the farmer level. So as to maintain the income of rubber farmers, the modify of rubber spacing through double rows should be developed to extending the period of gambier intercrops cultivation
\end{abstract}

Keywords: intercrops, gambir, rubber, income

\section{Pendahuluan}

Karet merupakan salah satu komoditas unggulan di provinsi Sumatera Selatan selain 
kelapa sawit. Luas areal perkebunan karet di Sumatera Selatan sebesar 838.749 ha. Luasan tersebut terdiri atas dari perkebunan rakyat sebesar 791.187 ha, perkebunan negara sebesar 11.334 ha dan perkebunan swasta sebesar 36.228 ha (Direktorat Jenderal Perkebunan, 2016). Luasan tersebut menjadikan perkebunan karet dapat meningkatkan perekonomian masyarakat. Kepala keluarga yang menjadikan perkebunan karet menjadi roda perekonomian keluarga sebesar 463.568 KK. Sehingga kondisi harga karet berperan penting pada mempengaruhi pendapatan keluarga petani. Harga karet pada beberapa tahun terakhir mengalami fluktuasi yang tajam. Berikut fluktuasi harga karet yang disajikan pada Gambar 1.

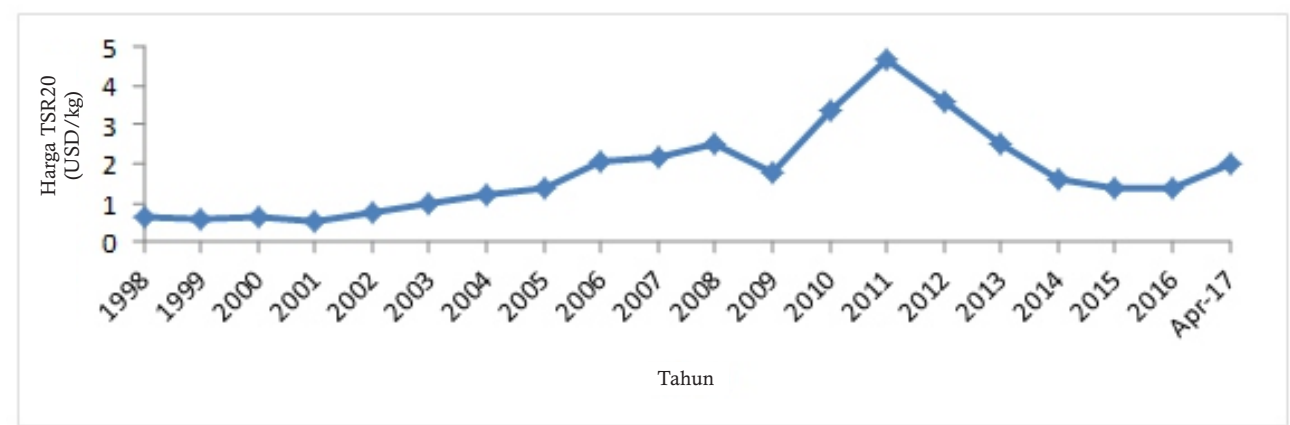

Sumber : Sicom, 2017

Gambar 1. Fluktuasi harga karet tahun 1998 - 2017

Gambar 1 menunjukkan bahwa fluktuasi harga karet sangat tinggi selama 10 tahun terakhir, harga karet tertinggi pernah mencapai USD 4,5 per kg pada tahun 2011. Penurunan harga karet secara langsung mempengaruhi pendapatan petani karet. Upaya mempertahankan pendapatan serta memenuhi kebutuhan keluarga maka petani harus dapat mencari kegiatan lain yang dapat menambah pendapatan petani. Ada beberapa cara yang dapat dilakukan petani karet untuk meningkatkan pendapatan petani karet yaitu petani yang kebunnya sudah menghasilkan (panen) melakukan pemasaran hasil panen secara berkelompok. Pemasaran yang berkelompok dapat menambah harga jual dari bahan olah karet (Bokar) (Alamsyah et al., 2017; Dompak, 2011). Sedangkan usaha meningkatkan pendapatan petani karet yang tanamannya belum menghasilkan, petani dapat dengan memanfaatkan lahan di gawangan karet ditanami dengan tanaman yang bernilai ekonomis (Kadekoh, 2007; Sahuri, 2017 ; Sahuri, 2017 ; Sahuri et al., 2016). Selain itu juga menanam tanaman sela dapat meminimalisasikan kompetisi antara gulma dan tanaman karet yang belum menghasilkan (Fikriati, 2010; Rosyid, 2007). Salah satu tanaman yang memiliki nilai ekonomis tinggi dengan memanfaatkan di gawangan karet yang belum menghasilkan adalah tanaman gambir..

Gambir (Uncaria gambir Roxb) adalah salah satu komoditas yang memiliki nilai ekonomis tinggi. Tanaman ini tersebar di wilayah Sumatera seperti Aceh, Sumatera Utara, Riau, Sumatera Selatan, Bengkulu, dan Sumatera Barat. Komoditas ini dapat dimanfaatkan untuk meningkatkan pendapatan petani karet melalui sistem usahatani terpadu yaitu sebagai tanaman sela karet. Sistem tersebut sangat membantu petani karena pada saat ini harga karet masih rendah dan dapat meningkatkan produktivitas lahan. Gambir merupakan tanaman spesifik lokasi karena tumbuh dan berproduksi tinggi di wilayah tertentu, termasuk desa Toman. Selain itu juga gambir termasuk tanaman perdu setengah merambat. Manfaat gambir adalah sebagai bahan obatobatan, pewarna alami dan lain-lain. Produksi gambir tertinggi terdapat di Sumatera Barat yang memberikan kontribusi sebesar $80 \%$ dari produksi gambir nasional. 
Desa Toman merupakan salah satu lokasi dimana tanaman gambir dapat tumbuh dan menghasilkan getah dibandingkan dari lokasi lain yang ada di daerah Sumatera Selatan. Kegiatan tersebut sudah sejak lama dilakukan di desa tersebut. Petani di desa Toman pada umumnya menanam gambir secara monokultur maupun polikultur. Namun, kebanyakan tanaman gambir dijadikan sebagai tanaman sela karet. Hal tersebut disebabkan tanaman karet merupakan tanaman yang turun menurun yang menjadi sumber penghasil pendapatan petani sejak dahulu sampai sekarang. Meskipun petani di desa Toman sudah terbiasa membudidayakan tanaman gambir dan karet, namun produktivitas dari tanaman tersebut tergolong belum maksimal. Oleh karena itu tulisan ini dilakukan bertujuan untuk mengkaji nilai tambah tanaman gambir untuk meningkatan pendapatan petani karet yang pada saat ini.

\section{Gambaran Umum Komoditi Gambir dan Karet di Musi Banyuasin}

Persyaratan tumbuh tanaman karet yang optimal adalah lahan kering bertekstur halus sampai sedang, ketinggian tempat 0-200 $\mathrm{m}$ di atas permukaan laut (mdpl), kedalaman tanah minimal $40 \mathrm{~cm}$, drainase yang baik, $\mathrm{pH}$ tanah (4,0-6,5), C-organik minimal $0,4 \%$, lama penyinaran matahari 5-7 jam/hari, suhu udara 24-30 ${ }^{\circ} \mathrm{C}$, curah hujan $1500-2500 \mathrm{~mm} /$ tahun, kelembaban udara 75-80 \% (Wijaya, 2008; Wijayanti \& Saefuddin, 2012). Persyaratan tumbuh tanaman gambir yang optimal adalah kering lahan bertekstur halus sampai sedang, ketinggian tempat 0-200 mdpl, kedalaman tanah minimal $40 \mathrm{~cm}$, drainase yang baik, $\mathrm{pH}$ tanah (5,5-7,8), C-organik minimal 0,4\%, lama penyinaran matahari $5-7 \mathrm{jam} / \mathrm{hari}$, suhu udara 26-28 ${ }^{\circ} \mathrm{C}$, curah hujan 1200-1600 $\mathrm{mm} /$ tahun, kelembaban udara 75-80 \% (Djaenudin etal., 2003).

Ditinjau dari persyaratan tumbuhnya, gambir dapat dikembangkan sebagai tanaman sela di antara karet. Permasalahan yang perlu diperbaiki adalah tingkat kemasaman tanah dan penyinaran matahari. Kemasaman tanah dapat diperbaiki melalui ameliorasi dengan kapur atau pupuk kandang dan pupuk kimia $\mathrm{N}, \mathrm{P}$ dan $\mathrm{K}$ yang optimal. Intensitas cahaya matahari yang kurang karena faktor naungan tajuk tanaman karet dapat diantisipasi dengan modifikasi jarak tanam karet melalui jarak tanam ganda.

Produktivitas getah gambir varietas Udang toleran tanah masam dan kekeringan yang dikembangkan di desa Babat Toman mampu mencapai 0,91 - 1,02 ton/ha pada tanaman karet berumur 1-2 tahun, sedangkan pada lahan terbuka mampu mencapai 1,17 - 1,51 ton/ha (Balai Penelitian Tanaman Industri, 2008). Jadi varietas tersebut berpeluang untuk dikembangkan pada areal tanaman karet yang secara umum diusahakan pada lahan kering masam dengan tanah podsolik merah kuning. Kesesuaian varietas gambir, teknologi budidaya dan agroklimat spesifik lokasi, ketepatan waktu dari berbagai tindakan agronomis, dan kesuburan tanah yang relatif baik dengan kandungan bahan organik, $\mathrm{P}_{2} \mathrm{O}_{5}$, dan $\mathrm{K}_{2} \mathrm{O}_{5}$ yang relatif baik sangat menentukan produktivitas gambir sebagai tanaman sela karet di lahan kering masam podsolik merah kuning.

Kegunaan gambir pada umumnya yaitu untuk obat-obatan seperti mengobati mencret (daunnya), perut mulas, eksema, disentri, radang gusi (getahnya), radang tenggorokan, demam-kuning, batuk, haid banyak dan berdarah. Seiring dengan perkembangan ilmu pengetahuan dan teknologi, gambir mempunyai efek sebagai sumber antioksidan alami. Senyawa antioksidan alami gambir adalah senyawa fenolik yang merupakan golongan flavonoid yang memiliki aktivitas antioksidan berupa katekin. Efek antioksidan tersebut dihubungkan dengan manfaat bagi kesehatan manusia dalam mencegah resiko penyakit degeneratif seperti kanker, jantung, diabetes, dan menghambat efek penuaan dini. Antioksidan juga diaplikasikan untuk memperpanjang masa simpan bahan pangan yang secara alami atau sengaja ditambahkan dalam produk pangan yang rentan terhadap oksidasi (Gordon, 2001). Luasnya pemanfaatan gambir yang digunakan sebagai bahan baku industri seperti industri tekstil, industri kosmetik, industri farmasi dan 
makanan yang menjadi indikasi adanya kandungan antioksidan dan antibakteri pada gambir sangat potensial untuk dikembangkan dalam memperpanjang masa simpan produk pangan.

Pemanfaatan gambir pada produk pangan selama ini masih terbatas sehingga menyebabkan gambir belum dimanfaatkan secara optimal serta kurangnya pengetahuan masyarakat dalam metode mengekstraksi gambir. Pengetahuan masyarakat tentang gambir masih terbatas berupa produk gambir komersil yang merupakan hasil ekstraksi daun tanaman gambir (Uncaria gambir Roxb) yang dikeringkan, diolah secara tradisional, diekstrak dengan metode basah menggunakan air sehingga gambir yang ada di pasaran masih dalam bentuk bongkahan serta merupakan ekstrak kasar. Ekstrak kasar tersebut, masih banyak terdapat komponen non fenolik sebagai bahan campuran impurities yang keberadaannya tidak dikehendaki seperti klorofil dan sellulosa. Komponen non fenolik tersebut akan mengganggu pengaplikasian dalam produk pangan sehingga perlu diekstraksi lagi untuk mendapatkan ekstrak gambir yang mengandung komponen fenolik bebas impurities serta memiliki aktivitas antioksidan yang tinggi (Rauf et al., 2010). Di pulau Sumatera, terdapat empat provinsi yang sentra utama perkebunan gambir yaitu : provinsi Sumatera Barat, Sumatera Utara, Riau dan Sumatera Selatan. Sebaran tanaman gambir di Indonesia dapat dilihat pada Tabel 1.

Sumatera Selatan merupakan salah satu produsen gambir di Indonesia, lokasinya terletak di desa Toman, kecamatan Babat Tomat kabupaten Musi Banyuasin. Komoditas ini juga sangat cocok untuk dikembangkan di desa Toman karena daerah ini memiliki kondisi iklim dan tanah yang mendukung, karena tanaman ini merupakan tanaman spesifik lokasi yang dapat tumbuh dan berkembang dengan baik pada kondisi lahan dengan jenis tanah podsolik merah kuning sampai merah kecoklatan. Selain itu, pertumbuhan tanaman gambir akan lebih baik apabila lahan tersebut tidak mudah tergenang oleh air, karena tanaman gambir tidak tahan dengan air yang akan menggenangi perakarannya. Oleh karena itu tanaman gambir masih tetap menjadi mata pencaharian penduduk desa Toman. Luas lahan gambir di desa Toman disajikan pada Tabel 2.

Berdasarkan Tabel 2 dapat dilihat bahwa luasan Tanaman Belum Menghasilkan (TBM) mengalami peningkatan setiap tahunnya karena adanya tanaman rusak diganti dengan tanaman yang baru sehingga meningkatkan Tanaman Belum Menghasilkan (TBM). Sedangkan luasan Tanaman Menghasilkan (TM) cenderung stabil, namun pada tahun 2015 luasan Tanaman Menghasilkan (TM) berkurang karena banyak tanaman gambir yang sudah tidak produktif. Luasan Tanaman Rusak (TR) pada tahun 2015 mengalami peningkatan yang signifikan yaitu sebesar $750 \%$ dari tahun 2010. Produksi gambir setiap tahunnya cenderung stabil, namun pada tahun 2015 terjadi peningkatan rata-rata produksi sebesar $110 \%$. Peningkatan tersebut salah satunya disebabkan oleh adanya peningkatan luasan lahan tanaman gambir sebesar $8 \%$ dari tahun 2010. Luasan lahan yang dimiliki per KK mengalami peningkatan hal tersebut dapat dilihat jumlah KK pada tahun 2015 lebih rendah dibandingkan tahun 2010 namun luasan lahan tahun 2015 lebih tinggi dibandingkan tahun 2010. Salah satu indikasi peningkatan jumlah luasan kepemilikan lahan gambir adalah adanya konversi lahan dari kebun karet menjadi kebun gambir. Konversi ini dilakukan karena beberapa tahun terakhir harga karet mengalami penurunan sehingga petani memilih untuk mengkonversi kebun karet menjadi kebun gambir. Gambir salah satu komoditas yang memiliki nilai ekonomis yang tinggi. Berdasarkan hasil penelitian Affandy (2007) menyatakan bahwa usahatani gambir sangat menguntungkan, hal tersebut dapat dilihat dari nilai Net B/C sebesar 7,25 dan memiliki Pay Back Periode 1 tahun 11,6 bulan dengan masa TBM selama 8 bulan setelah tanam. Berdasarkan kriteria tersebut usahatani gambir dapat dikatakan komoditas yang memiliki nilai ekonomis yang tinggi.

Selain gambir, perkebunan karet juga salah satu komoditas unggulan untuk meningkatkan pendapatan keluarga. Hal tersebut dapat dilihat pada Gambar 2 yang menunjukkan bahwa kabupaten Musi Banyuasin salah satu sentral perkebunan karet di provinsi Sumatera 
Tabel 1. Sebaran tanaman gambir di Indonesia

\begin{tabular}{|c|c|c|}
\hline No & Provinsi & Kabupaten/ Kota / Kecamatan \\
\hline 1 & Aceh & $\begin{array}{l}\text { Aceh Tenggara } \\
\text { - Kecamatan Bandar (Desa Tengku Kute, Kute Ujung) }\end{array}$ \\
\hline 2 & Sumatera Barat & $\begin{array}{ll}\text { 1. } & \text { Kabupaten Agam } \\
\text { 2. Kabupaten Pasaman } \\
\text { 3. Kabupaten Limapuluh Kota } \\
\text { - Kecamatan Bukit Barisan } \\
\text { - Kecamatan Guguk } \\
\text { - Kecamatan Mungka } \\
\text { - Kecamatan Payakumbuh } \\
\text { - Kecamatan Lareh Sago Halaban } \\
\text { - Kecamatan Harau } \\
\text { - Kecamatan Pangkalan Koto Baru } \\
\text { - Kecamatan Kapur IX } \\
\text { 4. Kabupaten Tanah Datar } \\
\text { 5. Kabupaten Padang Pariaman } \\
\text { 6. Kabupaten Solok } \\
\text { 7. Kabupaten Pesisir Selatan } \\
\text { 8. Kabupaten Sijunjung } \\
\text { 9. Kota Padang } \\
\text { 10 Kabupaten Sawah Lunto }\end{array}$ \\
\hline 3 & Sumatera Utara & $\begin{array}{l}\text { 1. Kabupaten Dairi } \\
\text { - Kecamatan Solok (Desa Tanjung Medan, dan Kuta Tinggi) } \\
\text { - Kecamatan Si Empa Nempu Hulu (Desa Kuta Tengah) } \\
\text { - Kecamatan Silima Pungga (Desa Kentara) } \\
\text { 2. Kabupaten Phakpak }\end{array}$ \\
\hline 4 & Riau & Kabupaten Kampar \\
\hline 5 & Bangka Belitung & Kabupaten Sunggailat - Bangka \\
\hline 6 & Sumatera Selatan & $\begin{array}{l}\text { Kabupaten Musi Banyuasin } \\
\text { - Kecamatan Babat Toman, Desa Toman }\end{array}$ \\
\hline 7 & Papua & Kabupaten Merauke \\
\hline
\end{tabular}

Sumber : Badan Pusat Statistik (2008)

Tabel 2. Luas lahan gambir, produksi gambir dan jumlah kepala keluarga

\begin{tabular}{|c|c|c|c|c|c|c|c|}
\hline \multirow[b]{2}{*}{ Tahun } & \multicolumn{4}{|c|}{ Luas lahan (ha) } & \multirow[b]{2}{*}{$\begin{array}{l}\text { Produksi } \\
\text { (ton) }\end{array}$} & \multirow[b]{2}{*}{$\begin{array}{l}\text { Produktivitas } \\
\text { (ton/ha/thn) }\end{array}$} & \multirow[b]{2}{*}{$\begin{array}{l}\text { Jumlah } \\
\text { TK/KK }\end{array}$} \\
\hline & $\begin{array}{c}\text { Tanaman } \\
\text { belum } \\
\text { menghasilkan }\end{array}$ & $\begin{array}{c}\text { Tanaman } \\
\text { menghasilkan }\end{array}$ & $\begin{array}{c}\text { Tanaman } \\
\text { rusak }\end{array}$ & Total & & & \\
\hline 2009 & 34 & 479 & 36 & 549 & 185 & 0,39 & 268 \\
\hline 2010 & 50 & 489 & 24 & 563 & 189 & 0,39 & 279 \\
\hline 2015 & 110 & 320 & 180 & 610 & 270 & 0,84 & 112 \\
\hline
\end{tabular}

Sumber: Dinas Perkebunan Sumatera Selatan (2016) 


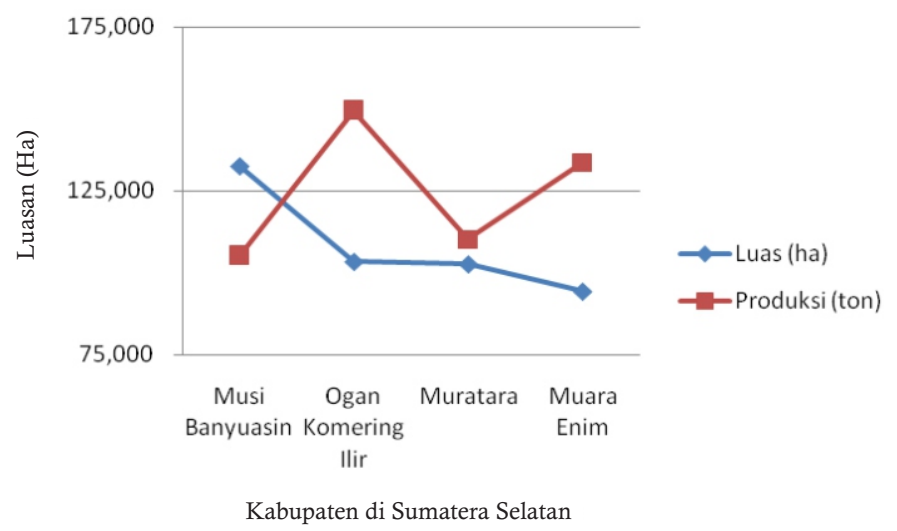

Sumber : Direktorat Jenderal Perkebunan (2016)

Gambar 2. Luasan dan produksi karet di kabupaten Sumatera Selatan tahun 2016.

Selatan. kabupaten Musi Banyuasin memiliki luasan Tanaman Belum Menghasilkan (TBM) sebesar 15.228 ha, TM sebesar 114.604 ha dan Tanaman Tua (TT) sebesar 2.692 ha. Jumlah kepala keluarga yang terlibat langsung kepada perkebunan karet sebanyak 69.674 KK (Dinas Perkebunan Sumatera Selatan, 2016) (Gambar 2).

Luasan areal tanaman karet di antara kabupaten se Sumatera Selatan yang tertinggi adalah kabupaten Musi Banyuasin, akan tetapi produktivitasnya masih rendah dibandingkan dengan sentra perkebunan karet lainnya. Hal ini disebabkan karena masih banyak petani yang menggunakan bukan klon unggul (sifat produktivitas tinggi, tahan HPT) bibit alam sehingga produktivitasnya rendah. Upaya meningkatkan pendapatan petani karet dengan kecenderungan harga karet yang rendah adalah penggunaan bibit unggul, peningkatan produksi tanaman karet, dan pemasaran karet secara terorganisir untuk meningkatkan posisi tawar petani sehingga harga karet dapat meningkat (Rakhma, 2015), selain hal tersebut peningkatan produktivitas lahan dapat dilakukan pula dengan integrasi dengan komoditi yang bernilai ekonomi tinggi (Rosyid et al., 2012; Sahuri et al., 2016; Sahuri \& Rosyid, 2015; Yuristia, 2017). Salah satu tanaman sela yang memiliki nilai ekonomis dan telah ditanam oleh petani adalah tanaman gambir. Berikut adalah kondisi tanaman gambir sebagai tanaman sela karet di desa Toman, kabupaten Musi Banyuasin.
Gambar 3 menunjukkan bahwa kondisi tanaman sela gambir diantara karet dilakukan masih secara tradisional sehingga tidak memperhatikan jarak tanam gambir dan karet. Kondisi jarak tanam yang rapat akan menimbulkan pertumbuhan karet yang terhambat serta adanya persaingan hara, air dan makanan selain itu juga pemanenan tanaman gambir sulit karena jarak tanam gambir sangat rapat. Jarak tanam yang dilakukan petani dengan ukuran 1,5 m x 1,5 m dan jarak tanaman karet ke tanaman gambir hanya $0,5 \mathrm{~m}$ sedangkan untuk jarak yang ideal adalah minimal jarak $2 \mathrm{~m} \times 2 \mathrm{~m}$ dengan jarak tanaman gambir ke tanaman karet 1-1,5 m. Ukuran tersebut baik untuk pertumbuhan dan mudah pada saat pemeliharaan dan pemanenan tanaman gambir dan karet Karena jarak tanaman sela ke tanaman karet tidak rapat sehingga tidak terjadi persaingan unsur hara dan air.

\section{Pemasaran Gambir dan Karet}

Getah gambir diproduksi dengan tujuan diekspor dan sebagian kecil (5,0\%) dipasarkan dalam negeri. Ekspor gambir berfluktuasi dari tahun ke tahun, hal ini tergantung pada ketersediaan produksi. Tanaman gambir cukup prospektif karena memiliki banyak manfaat karena semakin berkembangnya berbagai industri seperti kosmetik dan medis yang membutuhkan kandungan kimia dari gambir sebagai bahan penolong seperti 


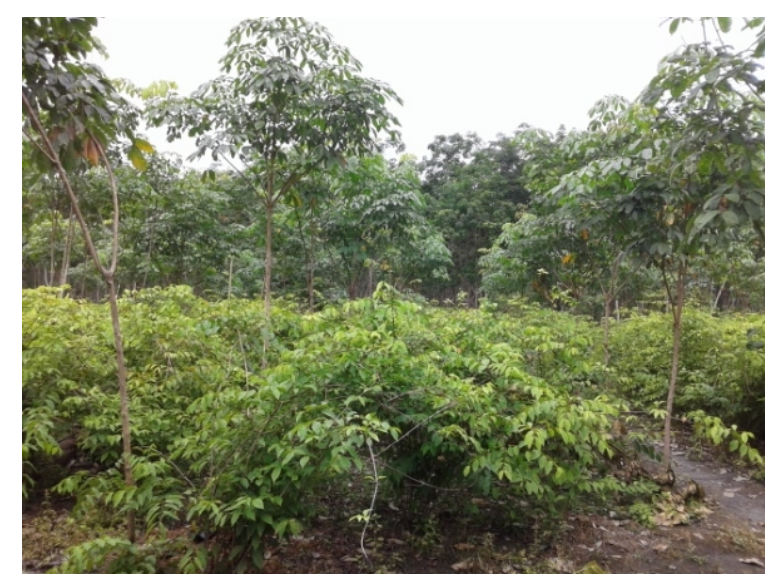

Gambar 3. Keragaan pola tumpangsari karet dan gambir diantara karet TBM berumur 2 tahun

penyamak kulit, pewarna batik dan lainnya. Prospek pemasaran komoditas gambir cukup cerah maka perlu diupayakan perbaikan dalam budidaya, pengolahan, mutu dan strategi pemasaran. Disamping itu masih terbuka luas penelitian mengenai diversifikasi pemanfaatan gambir. $\mathrm{Hal}$ ini sangat penting dilakukan sehingga komoditas ini memiliki keunggulan komparatif dan kompetitif di dalam perdagangan internasional (Novizar, 2000).

Berikut adalah Gambar 4 menjelaskan rantai pemasaran gambir dari petani sampai kepada eksportir. Gambar 4 menunjukkan bahwa harga yang diterima oleh petani gambir tergolong rendah, hal tersebut dapat dilihat bagian harga yang diterima petani hanya sebesar $43,1 \%$. Harga di tingkat petani sangat beragam karena memiliki rantai pemasaran yang panjang. Salah satu upaya untuk meningkatkan harga gambir dengan memperpendek rantai pemasaran (Astria, 2012).

Pemasaran karet juga hampir sama dengan gambir yaitu memiliki rantai pemasaran yang panjang. Pada saat ini petani karet yang sudah menggunakan sistem pemasaran terorganisir baru 2\%. Sedangkan sisanya masih menggunakan sistem pemasaran tradisional. Pemasaran yang terorganisir merupakan pemasaran yang memperpendek rantai pemasaran yaitu petani secara kolektif mengumpulkan hasil kebun kemudian petani tersebut akan melakukan mitra dengan pabrik maupun petani mengundang utusan pabrik untuk ikuti lelang hasil kebun petani. Sistem pemasaran tersebut sangat mampu meningkatkan bagian harga yang diterima oleh petani. Selisih harga yang diterima oleh petani yang menggunakan pemasaran terorganisir mencapai Rp 2.000 - Rp 3.000,perkg.

\section{Pendapatan Usahatani Gambir dan Karet di Desa Toman}

Usahatani gambir dan karet merupakan sumber pendapatan keluarga yang perlu dipertahankan. Kebun karet yang belum menghasilkan sampai umur 5 tahun dapat dimanfaatkan untuk berusahatani gambir. Tanaman gambir ini dapat menjadi nilai tambah petani karet sebelum tanaman karet menghasilkan. Usahatani gambir masih dapat dilakukan pada tanaman karet yang menghasilkan, namun produksinya tidak maksimal. Produksi yang tidak maksimal disebabkan salah satunya adalah tajuk tanaman karet telah rapat sehingga fotosintesis tanaman gambir tidak mendapatkan cahaya matahari yang optimal sehingga metabolisme tanaman tidak maksimal karena getah gambir berasal dari metabolit sekunder tanaman oleh karena itu dibutuhkan cahaya matahari yang cukup untuk proses fotosintesis dan metabolisme tanaman.

Tanaman gambir dapat dipanen pada umur 8-12 bulan setelah tanam, sedangkan tanaman karet pada umumnya dapat dipanen setelah 


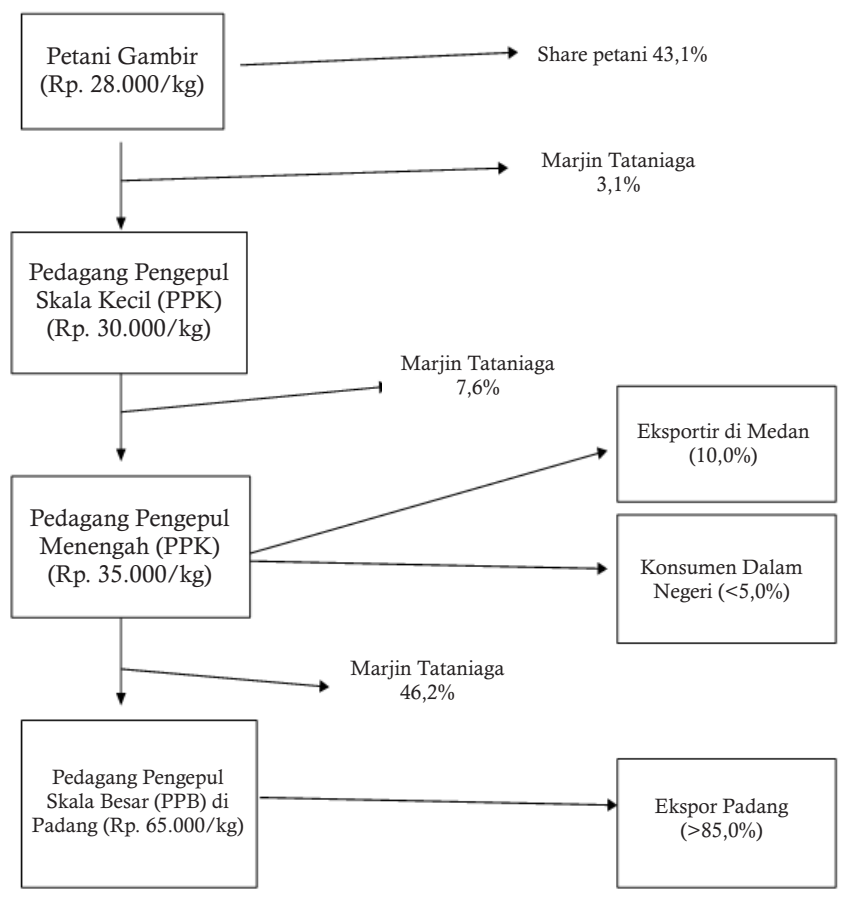

Sumber : Hosen (2017)

Gambar 4. Rantai pemasaran gambir dari petani sampai ke eksportir

mencapai umur 5 tahun. Sehingga dengan kondisi tersebut pada petani hanya dapat menanam gambir pada saat tahun pertanaman karet saja tidak mendapatkan hasil. Tanaman gambir dengan pola pemanenan yang baik dapat dipanen setiap hari. Pada umumnya petani gambir di desa Toman memanen gambir 4 hari dalam satu minggu dengan hasil gambir rata-rata 22 jaras per hari ( 1 jaras terdiri dari 30 stik gambir yang siap jual). Untuk harga gambir yang dibeli oleh tengkulak sebesar Rp $17.000,-$ per jaras. Pendapatan dari gambir dan karet disajikan pada Tabel 3.

Berdasarkan Tabel 3 dapat dilihat bahwa pendapatan gambir lebih tinggi dibandingkan dengan pendapatan dari karet. Kondisi tersebut disebabkan mulai tahun 2013 harga karet dunia mulai mengalami penurunan drastis sehingga berdampak kepada harga karet di tingkat petani Sehingga pendapatan petani karet hanya mencapai Rp 2.507.500,per bulan. Meskipun harga karet rendah, petani masih tetap mengandalkan karet sebagai sumber pendapatan keluarga karena sudah usaha ini yang telah lama dijalankan oleh petani. Pendapatan dari gambir pada saat ini tergolong rendah karena harga gambir masih di level Rp 17.000,- per jaras. Rendahnya harga gambir disebabkan salah satu panjangnya rantai pemasaran sehingga banyak bagian harga yang diterima oleh petani menjadi rendah (Harun, 2011; Yuristia, 2017). Pendapatan gambir mencapai Rp 2.792.944,per bulan tersebut sesuai dengan hasil penelitian sebelumnya yang menyatakan bahwa pendapatan dari usahatani gambir mencapai hampir 3 juta (Affandy, 2007). Tanaman sela gambir ini sangat membantu peningkatan pendapatan petani sehingga ekonomi keluarga dapat terbantu (Anggriawan \& Indrawati, 2013). Hal tersebut seiring dengan harga karet yang belum stabil. Sehingga untuk menjadikan pendapatan petani karet lebih stabil maka usahatani gambir tetap dipertahankan serta dengan mengubah jarak tanam karet dari $5 \mathrm{~m} \times 3 \mathrm{~m}$ menjadi jarak tanam lebar. Perubahan jarak tanam karet tersebut diharapkan usahatani gambir akan dapat berproduksi sampai 15-20 tahun. 
Tabel 3. Pendapatan tanaman sela gambir dan karet

\begin{tabular}{clcc}
\hline No & \multicolumn{1}{c}{ Uraian } & Gambir & Karet \\
\hline 1 & Penerimaan (Rp/bulan) & 5.984 .000 & 3.200 .000 \\
2 & Biaya Produksi (Rp/bulan) & 3.191 .056 & 692.500 \\
3 & Pendapatan (Rp/bulan) & 2.792 .944 & 2.507 .500 \\
\hline
\end{tabular}

\section{Kendala Pengembangan Tanaman Gambir di Perkebunan Karet}

Secara teknis pengembangan gambir pada lahan kering di bawah tegakan tanaman karet adalah rendahnya intensitas cahaya karena faktor naungan tajuk tanaman karet. Hal ini karena secara umum di Indonesia, petani menanam karet menggunakan jarak tanam tunggal yaitu $6 \mathrm{~m} \times 3 \mathrm{~m}$ (550 pohon/ha) atau 7 m x 3 m (476 pohon/ha) (Rosyid et al., 2007). Jarak tanam karet tersebut hanya dapat ditanami tanaman sela gambir sampai tanaman karet berumur 1-2 tahun (Pathiratna, 2006; Rosyid et al., 2012). Luas areal yang dapat dimanfaatkan untuk tanaman sela sekitar $50-60 \%$ dari luas areal tanaman karet (Rosyid et al., 2012; Sahuri \& Rosyid, 2015; Sahuri et al., 2016; Sahuri, 2017ª). Namun, dengan jarak tanam karet tersebut ketika tanaman karet berumur $>2$ tahun, tajuk tanaman karet sudah saling menutup dengan pengurangan intensitas cahaya mencapai 5060\% (Wirnas, 2007; Xiaongfei \& Negfa, 2004). Tanaman gambir yang ditanam di bawah naungan kurang dari $50 \%$ mengalami penurunan hasil mencapai $60 \%$, dibandingkan dengan keadaan tanpa naungan (Rosyid et al., 2012).

Secara sosial petani di desa Toman sudah terbiasa berusahatani gambir di antara tanaman karet. Namun areal perkebunan karet rakyat umumnya terletak relatif jauh dari jalan utama dengan prasarana jalan yang kurang baik, belum mempunyai fasilitas pasar, dan jauh dengan pusat informasi/penyuluhan, serta belum berada di dalam atau sekitar proyek pengembangan usahatani gambir yang berhasil sebagai tanaman sela karet. Secara umum petani karet rakyat belum mengetahui banyak tentang keberadaan teknologi usahatani gambir sebagai tanaman sela karet yang direkomendasikan, sehingga motivasi mereka untuk mengadopsi teknologi anjuran pada umumnya juga masih rendah. Kelembagaan sosial ekonomi petani di desa belum maju biasanya masih lemah, baik dalam kegiatan maupun pengelolaan organisasinya.

Secara ekonomi lembaga alih teknologi dan permodalan di pedesaan masih lemah terutama di daerah sentra perkebunan karet rakyat. Oleh karena itu, kegiatan agribisnis gambir yang membutuhkan dukungan teknologi dan pemodalan yang relatif besar seperti pengeringan, penyimpanan, dan pengolahan hasil sulit dijalankan. Hal ini perlu diperhatikan dalam pengembangan usahatani gambir sebagai tanaman sela karet agar dapat diadopsi oleh petani.

\section{Inovasi Teknologi dan Kelembagaan Pengembangan Tanaman Gambir di Perkebunan Karet}

Kendala naungan akibat tajuk tanaman karet dalam pengembangan gambir sebagai tanaman sela dapat diatasi melalui modifikasi jarak tanam karet dari Jarak Tanam Tunggal (JT) ke Jarak Tanam Ganda (JG) (Xiaongfei \& Negfa, 2004; Sahuri, 2017ª). Populasi karet per hektar dengan jarak tanam ganda (400-435 pohon/ha) kurang dari populasi dengan jarak tanam tunggal (476-500 pohon/ha). Namun pertumbuhan dan produksi karet tidak berbeda nyata dibandingkan dengan jarak tanam tunggal (Sahuri 2017). Selain itu, jarak tanam ganda dapat memperpanjang masa tanaman sela yang diusahakan bahkan diseluruh rentang produksi tanaman karet karena penetrasi cahaya lebih tinggi (Xianhai et al., 2012; Sahuri, 2017 ). Pada jarak tanam ganda juga tanaman karet lebih mudah mendapatkan 
penyinaran matahari, suhu dan air (Xiaongfei \& Negfa, 2004). Jarak tanam ganda $14,1 \mathrm{~m}+$ $(2,4 \mathrm{~m} \times 2,4 \mathrm{~m})(500$ pohon/ha), dapat ditanami tanaman sela sampai umur karet $>5$ tahun dengan intensitas cahaya masih $70-80 \%$. Jarak tanam ganda $12 \mathrm{~m}+(4 \mathrm{~m} \times 2.5 \mathrm{~m})(500$ pohon/ha), dapat ditanami tanaman sela sampai umur karet $>4$ tahun dengan intensitas cahaya masih 60-70\% (Rosyid et al., 2012). Jarak tanam ganda $20 \mathrm{~m}+(4 \mathrm{~m} \times 2 \mathrm{~m})(417$ pohon/ha) dapat ditanami tanaman sela diseluruh rentang produksi tanaman karet (Xianhai et al., 2012). Jarak tanam ganda (18 m $+2,5 \mathrm{~m}) \times 2 \mathrm{~m}(400$ pohon/ha) dapat ditanami tanaman sela dalam jangka panjang dan memiliki ketahanan terhadap angin (Raintree, 2005). Pertumbuhan lilit batang karet dan hasil. Hasil lateks per pohon sistem JT dan sistem jarak ganda (JG) tidak signifikan. Namun hasil lateks per hektar sistem JT lebih tinggi dari sistem JG karena populasi dari sistem JT lebih dari sistem JG. Pada saat tanaman karet berumur 8-9 tahun pada sistem JT penetrasi cahaya kurang dari 30\% pada setiap titik yang diukur. Sementara itu, penetrasi cahaya pada sistem JG lebih dari $80 \%$ setelah $4 \mathrm{~m}$ dari baris karet (Xianhai et al., 2012; Sahuri, 2017 ${ }^{a}$ ). Dengan demikian sistem JG menjadi sistem tanam karet yang cocok untuk tumpangsari berbasis karet jangka panjang.

Kendala tanah masam dapat diatasi dengan menggunakan varietas gambir toleran tanah masam dan kekeringan serta disertai perbaikan kesuburan tanah melalui ameliorasi dengan kapur (dolomit atau kalsit) atau bahan organik serta pemupukan $\mathrm{N}, \mathrm{P}$, dan $\mathrm{K}$ yang optimal. Penggunaan varietas gambir toleran lahan kering masam merupakan kunci utama untuk memperoleh hasil gambir yang tinggi. Kriteria varietas gambir yang digunakan pada pola tanam gambir sebagai tanaman sela karet adalah berdaya kecambah tinggi $>80 \%$, mempunyai vigor yang baik, murni tidak tercampur oleh varietas lain dan sehat bebas organisme pengganggu tanaman. Selain itu, beradaptasi dengan baik di dataran rendah $<$ 200 meter dari permukaan laut (mdpl) sesuai dengan agroekologi tanaman karet (Wijaya, 2008). Varietas Udang toleran tanah masam dan kekeringan dan merupakan varietas spesifik lokasi di desa Toman mampu berproduksi mencapai 0,91 - 1,02 ton/ha pada tanaman karet berumur 1-2 tahun, sedangkan pada lahan terbuka mampu mencapai 1,17 1,51 ton/ha (Balai Penelitian Tanaman Industri, 2008). Oleh karena itu, varietas tersebut berpotensi untuk dikembangkan pada areal tanaman karet sebagai tanaman sela.

Kendala sosial dan ekonomi dalam pengembangan usahatani gambir di antara tanaman karet rakyat dapat diatasi melalui Model Kelembagaan Partisipatif. Suatu sistem usahatani gambir di suatu wilayah akan berhasil apabila didukung oleh kelembagaan partisipatif yang kuat. Oleh karena itu, diperlukan kebijakan pemerintah untuk membangun atau memperkuat kelembagaan partisipatif antara lain: 1) lembaga pemberdayaan dan penguatan sumberdaya manusia (SDM) petani melalui pelatihan teknis usahatani, pelatihan pemberdayaan petani, 2) lembaga prasarana pertanian sebagai penyediaan sarana produksi yang diperlukan terutama benih varietas unggul gambir dan bermitra dengan produsen pupuk dan obatobatan untuk meningkatkan efisiensi usahatani, 3) lembaga pemodalan sebagai alternatif pembiayaan yang berasal dari petani sendiri, mitra usaha, penyandang dana (Pemda, BUMN), dan Kredit Usahatani Tani yang oleh pemerintah dikhususkan untuk usaha intensifikasi padi, palawija, dan hortikultura, 4) lembaga pengolahan hasil, penyimpanan dan pemasaran untuk menjadi faktor penyangga harga gambir di tingkat usahatani, 4) lembaga penyuluhan dan pelayanan informasi sebagai sumber teknologi, 5) pengembangan pilot proyek atau diseminasi teknologi untuk mengetahui adaptasi teknologi di tingkat petani.

Kelembagaan-kelembagaan tersebut sebaiknya dibangun di wilayah pengembangan dan pembangunan usahatani gambir sebagai tanaman sela karet sehingga mempermudah petani dalam melaksanakan sistem usahataninya. Selain itu, pengaturan kelembagaan sangat penting untuk pembangunan usahatani gambir di antara tanaman karet rakyat. Oleh karena itu, 
diperlukan komitmen yang kuat dari pimpinan eksekutif dan legislatif pemerintah daerah (Pemda) setempat sangat dibutuhkan untuk memperlancar pelaksanaan kegiatan proyek. Peranan pimpinan legislatif dibutuhkan untuk mengartikulasikan kepentingan petani dan menjamin ketersediaan anggaran dalam kegiatan usahatani gambir sebagai tanaman sela karet dalam rencana anggaran Pemda maupun Pusat. Peranan pimpinan eksekutif dibutuhkan untuk mengkoordinasikan, mensinergikan, dan menggerakkan semua sumberdaya dan komponen yang terlibat dalam kegiatan pembangunan.

\section{Kesimpulan}

Pemanfaatan lahan di sela tanaman karet menggunakan tanaman gambir sudah dikembangkan secara luas di desa Toman. Pola tanam ini merupakan salah satu cara yang digunakan untuk meningkatkan pendapatan petani karet pada saat kondisi harga karet mengalami penurunan. Pendapatan yang dihasilkan dari usahatani gambir lebih tinggi $11 \%$ dibandingkan dari pendapatan karet setiap bulannya. Penghasilan total yang diterima petani sebesar Rp 5.300.444,-- per bulan. Penghasilan tersebut dapat ditingkatkan jika petani menggunakan tataniaga yang efektif memotong mata rantai pemasaran yang panjang. Untuk menjaga keberlangsungan tanaman sela gambir diperlukan inovasi jarak tanam lebar yaitu dengan menggunakan jarak tanam $19 \mathrm{~m} \mathrm{x} 4 \mathrm{~m}$ x $2 \mathrm{~m}$. Dengan pengembangan jarak tanam lebar ini akan meningkatkan pendapatan petani kareat maupun petani gambir serta perlunya peran pemerintah untuk penguatan kelembagaan untuk memasarkan komoditi unggulan desa Toman

\section{Daftar Pustaka}

Affandy, M. (2007). Analisis kelayakan finansial usahatani gambir di desa toman kecamatan babat toman kabupaten musi banyuasin provinsi sumatera selatan. (Skripsi), Institut Pertanian Bogor, Bogor.
Alamsyah, A., Nugraha, I. S., Agustina, D. S., \& Vachlepi, A. (2017). Tinjauan penerapan unit pengolahan dan pemasaran bokar untuk mendukung gerakan nasional bokar bersih di sumatera selatan. Warta Perkaretan, 36(2), 159-172.

Anggriawan, \& Indrawati, T. (2013). Peranan komoditi gambir terhadap perekonomian kabupaten lima puluh kota provinsi sumatera barat. Jurnal Ekonomi, 21(2), 1-21.

Astria, P. (2012). Hubungan antara tauke dan petani gambir (studi kasus: Hubungan patron klien di nagari siguntur kecamatan koto xi tarusan kabupaten pesisir selatan provinsi sumatera barat). (Skripsi), Universitas Andalas, Padang.

Badan Pusat Statistik. (2008). Indikator Kesejahteraan Rakyat. Jakarta, Indonesia: Badan Pusat Statistik.

Balai Penelitian Tanaman Industri. (2008). Teknologi peremajaan gambir (uncaria gambir roxb). Bogor, Indonesia: Sirkuler Teknologi Tanaman Rempah dan Industri.

Dinas Perkebunan Sumatera Selatan. (2016). Statistik perkebunan 2015 : Menuju satu angka statistik perkebunan secara nasional. Palembang, Indonesia: Dinas Perkebunan Sumatera Selatan.

Direktorat Jenderal Perkebunan. (2016). Statistik Perkebunan Indonesia 2015-2017 Karet. Jakarta, Indonesia: Kementerian Pertanian.

Djaenudin, D., Marwan, A., Hidayat, \& Subagyo. (2003). Petunjuk teknis evaluasi lahan untuk komoditas pertanian. Bogor, Indonesia: Badan Penelitian dan Pengembangan Pertanian.

Dompak, N. (2011). Kajian tata niaga karet alam : Upaya peningkatan kesejahteraan petani. Jurnal Penelitian Karet, 29(1), 76-92.

Fikriati, M. (2010). Uji daya hasil lanjutan kedelai (glycine max (l) merr) toleran naungan di bawah tegakan karet rakyat di kabupaten sarolangun jambi. (Skripsi), Institut Pertanian Bogor, Bogor.

Gordon, M. H. (2001). Measuring antioxidant activity. In J. Pokorny, Nedyalka, Y. Malarova, \& M. Gordon (Eds.), Antioxidant in food practical application. London, UK: Woodhead Publishing Ltd. 
Harun, E. W. (2011). Analisis faktor-faktor yang mempengaruhi volume ekspor gambir (uncaria gambier roxb) sumatera barat. Diakses dari Fakultas Pertanian Universitas Andalas, Padang.

Hosen, N. (2017). Profile of agribussiness of smallholder gambier plantation in west sumatera. Jurnal Penelitian Pertanian Terapan, 17(2), 124-131.

Kadekoh. (2007, 24-25 Juli). Optimasi pemanfaatan lahan kering berkelanjutan dengan sistem polikultur. Tulisan disajikan pada Seminar Nasional Pengembangan Inovasi Lahan Marginal, Palu.

Novizar, N. (2000). Gambir budidaya, pengolahan dan prospek diversifikasinya. Padang, Indonesia: Yayasan Hutanku.

Pathiratna, L. S. S. (2006). Management of intercrops under rubber: implications of Competition and possibilities for improvement. Bulletin of the Rubber Research Institute of Sri Lanka, 47, 8-16.

Raintree, J. (2005). Intercropping with rubber for risk management. In: Improving livelihoods in the upland of the lao pdr: Options and opportunities. National agriculture and forestry research institute (nafri), national agriculture and forestry extension service (nafes), an. National University of Lao PDR (NUOL), 2(1), 41-46.

Rakhma, M. (2015). Marketing system of smallholder rubber in the jambi province indonesia (batang hari, sarolangun and tebo regency). (Skripsi), Institut Pertanian Bogor, Bogor.

Rauf, R., Santoso, U., \& Suparmo. (2010). Aktivitas penangkapan radikal dpph ekstraak gambir (uncaria gambir roxb.). Agritech, 30(1), 1-5.

Rosyid, M. J. (2007). Pengaruh tanaman sela terhadap pertumbuhan karet pada areal peremajaan partisipatif di kabupaten sarolangun jambi. Jurnal Penelitian Karet, 25(2), 25-36.

Rosyid, M., Wibawa, G., \& Gunawan, A. (2012). Saptabina usahatani karet rakyat. In S. Ismawanto, J. Saputra, L. F. Syarifa, \& M. Purbaya (Eds.), Pola Tanaman Sela. Palembang: Balai Penelitian Sembawa.
Sahuri. $\left(2017^{\mathrm{a}}\right)$. Pengaturan pola tanam karet (hevea brasiliensis muell. Arg) untuk tumpangsari jangka panjang. Jurnal Ilmu Pertanian Indonesia, 22(1), 46-51.

Sahuri. $\left(2017^{b}\right)$. Peningkatan produktivitas lahan dan pendapatan petani melalui tanaman sela pangan berbasis karet. Jurnal Lahan Sub Optimal, 6(1), 33-42.

Sahuri, Cahyo, A. N., \& Nugraha, I. S. (2016). Pola tumpangsari karet-padi sawah pada tingkat petani di lahan pasang surut sumatera selatan. Warta Perkaretan, 35(2), 107-120.

Sahuri, \& Rosyid, M. (2015). Analisis usahatani dan optimasi pemanfaatan gawangan karet menggunakan cabai rawit sebagai tanaman sela. Warta Perkaretan, 34(2), 77-88.

Wijaya, T. (2008). Kesesuaian tanah dan iklim untuk tanaman karet. Warta Perkaretan, 27(2), 34-44.

Wijayanti, T., \& Saefuddin. (2012). Analisis pendapatan usahatani karet (hevea brasiliensis) di desa bunga putih kecamatan marang kayu kabupaten kutai kartanegara. Jurnal Zira'ah, 34(2), 137-148.

Wirnas, D. (2007). Pemilihan karakter seleksi berdasarkan analisis biometrik dan molekuler untuk merakit kedelai toleran intensitas cahaya rendah. (Disertasi Doktor), Institut Pertanian Bogor, Bogor.

Xianhai, Z., Mingdao, C., \& Weifu, L. (2012). Improving planting pattern for intercropping in the whole production span of rubber tree. African Journal of Biotechnology, 11(34), 8484-8490.

Xiaongfei, Y., \& Negfa. (2004). Intercropping pattern and their development in rubber plantations in dehong district yunan china. Tulisan disajikan pada IRRDB Symposium, Beijing.

Yuristia, R. (2017). Pemasaran gambir (uncaria gambir roxb) di kenagarian manggilang kecamatan koto baru kabupaten lima puluh kota. Jurnal Pertanian UMSB, 1(1), 17-24. 